\title{
The Rest of The StORY OF $R$. V. STINCHCOMBE: A Case Study in Disclosure Issues
}

\author{
JOHN KINGMAN PHILLIPS
}

Stinchcombe is a decision which is oft-quoted but not well understood or properly interpreted by the courts. This article reviews the facts of the Stinchcombe litigation and suggests that the Courts have failed to properly apply the principles enunciated therein. In the initial Supreme Court decision Sopinka J. suggested the adoption of the civil model of pretrial disclosure in the criminal context: the Crown, he suggested, should err on the side of inclusion and consider it a constitutional duty to disclose everything that could be relevant to the case. The courts have failed to properly apply this decision, as evidenced by the judicial interpretation of "relevance." the expectation that defence counsel will police prosecutors' compliance with the disclosure obligation, and the failure of the courts 10 apply appropriate remedies or sanctions where disclosure obligations have not been properly met. The author suggests that practitioners should reconsider the principles of Stinchcombe, especially in light of proposed changes to the Alberta Rules of Court which might make disclosure requirements in the civil process less stringent.
La décision Stinchcombe en est une qui est souvent citee. mais rarement bien comprise ou correctement interprétée par les tribunaux. L'auteur de cet article revoit les faits du procès de l'affaire Stinchcombe et laisse entendre que les tribunaux $n$ 'ont pas correctement appliqué le principe qui y est formulé. Dans la première décision de la Cour suprème, le juge Sopinka a suggéré l'adoption du modele civil de la communication de la preuve avant le procès dans le contexte criminel. Il a suggéré que la Couronne erre plutôt dans le sens de l'inclusion et estime qu'il est de son devoir constitutionnel de communiquer tout ce qui est pertinent $\dot{a}$ l'affaire. Les tribunaux $n$ 'ont pas bien appliqué cette décision. comme en témoigne l'interprétation judiciaire de "pertinence "I'attente que l'avocat de la défense voit à ce que les procureurs se conforment $\dot{a}$ l'obligation de communiquer et le défaut des tribunaux d'appliquer des remèdes ou des sanctions appropriés lorsque ces obligations ne sont pas correctement respectées. L'auteur suggère que les praticiens revoient les principes de Stinchcombe, surlout à la lumière des changements proposés aux règles de procédure de l'Alberla qui pourraient alleger les exigences de communiquer dans un contexte civil.

\section{Table of Contents}

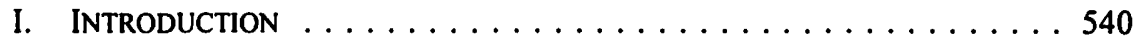

II. BACKGROUND: $R$. v. STINCHCOMBE $\ldots \ldots \ldots \ldots \ldots \ldots \ldots \ldots 54$

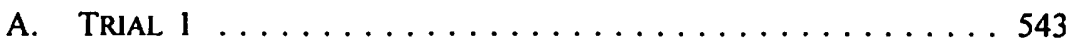

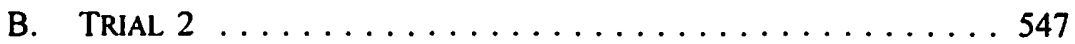

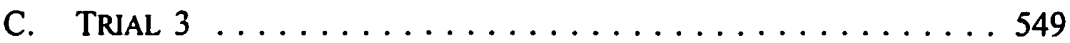

D. THE END OF THE STORY - ADMINISTRATIVE

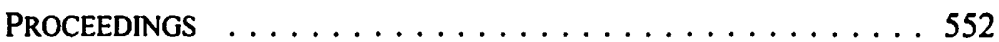

III. The Civil Discovery Paradigm — A FaILed Model . . . . . 554

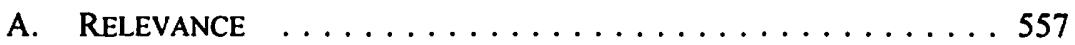

B. ReMEdies AND SANCTIONS $\ldots \ldots \ldots \ldots \ldots \ldots \ldots \ldots 58$

B.A. (Saskatchewan), LL.B. (Osgoode), M.A. (Guelph). The author is a member of the Law Societies of Alberta and Upper Canada and is affiliated with Heenan Blaikie LLP in Calgary and Paliare Roland LLP in Toronto, where he practices in the areas of civil and criminal litigation. He is also appointed as an Adjunct Assistant Professor with the Faculty of Law, University of Calgary. Phillips was co-counsel with W.E. Code, Q.C. for the appeal from the original trial judgment to the Alberta Court of Appeal and on further appeal to the Supreme Court of Canada in $R$. v. Stinchcombe, [1991] 3 S.C.R. 326 and, subsequently, assisted R.G. Mitchell in Trial 2 and through the remainder of the proceedings in the criminal prosecution. 
VOL. $40(3) 2002$

\section{THE FAILED PARAdIGM AND LesSONS FOR}

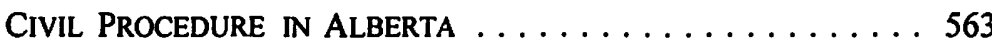

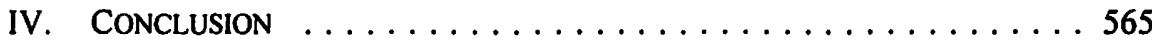

\section{INTRODUCTION}

Shortly after the release of the Reasons for Judgment of the Supreme Court of Canada in $R$. v. Stinchcombe in November 1991, an article was published in the Criminal Reports titled "Stinchcombe: Bad Case, Good Law?"2 As the opening lines of the article suggest, ${ }^{3}$ the facts of Stinchcombe were alleged to present a "bad case" and the law that flowed therefrom, namely the broad disclosure principles that were articulated, may have been ill-conceived or "bad law." While the impact of the decision was immediate and widely applauded by the defence bar and, in some cases, by members of the Crown prosecutors' office, the general impression was that the facts of the case were of little consequence or, worse, were unsupportive of the principles enunciated therein.

Although the decision of the Supreme Court of Canada in Stinchcombe is perhaps the most frequently cited authority in Canadian criminal law, little is known by the members of the Bar of the actual facts of the case - and even less is known of the subsequent history of the case against Stinchcombe and its convoluted process through the courts. The history of the case, which wound its way through three trials, ${ }^{4}$ two appearances in the Supreme Court of Canada, ${ }^{5}$ and numerous civil and administrative proceedings, ${ }^{6}$ provides fertile ground for an analysis of almost all aspects of the law of disclosure.

This article will review the judicial history and underlying facts of the case against Stinchcombe to provide members of the Bar with an understanding of the rest of those proceedings. The proceedings are interesting in their own right, and will also serve as a means of introducing the following articles in this issue of the Alberta Law Review. The latter part of this article will focus on what this author perceives to be the serious failure of subsequent decisions of the Supreme Court of Canada and lower courts to effectively adopt the paradigm of disclosure articulated by Sopinka J. in Stinchcombe. The conclusion drawn is that the failure of the courts to take seriously the paradigm of civil discovery procedure creates a substantial risk that Stinchcombe will fail to achieve

[1991] 3 S.C.R. 326 [hereinafter Stinchcombe].

B. Glover, "Stinchcombe: Bad Case, Good Law?" (1992) 8 C.R. (4th) 307.

The opening lines of the article are as follows: "Do bad cases make bad law? On its facts, $R$. v. Stinchcombe ... was a bad case." Ibid. at 307.

- R. v. Stinchcombe (20 February 1989), Calgary 8801-1288-CO (Alta. Q.B.) [hereinafter Trial 1]; $R$. v. Stinchcombe (5 October 1992), Calgary 8801-1288-CO (Alta. Q.B.) [hereinafter Trial 2]; $R$. v. Stinchcombe (22 March 1996), Calgary 8801-1288-CO (Alta. Q.B.) [hereinafter Trial 3].

s $\quad R$ v. Stinchcombe, [1991] 3 S.C.R. 326; $R$ v. Stinchcombe, [1996] I S.C.R. 754 [hereinafter Stinchcombe No. 2].

Including the most recent installment in April 2002, which was a decision of the Alberta Court of Appeal in Stinchcombe v. Law Society of Alberta (2002), 303 A.R. 67, in an administrative law context. 
the vision articulated by Sopinka J. The failure to take the paradigm seriously can be seen in the definition of "relevancy," the role of the defence in policing and enforcing the Crown's disclosure obligation, and the remedies and sanctions imposed when the Crown fails to comply with its disclosure obligations. As a result, Stinchcombe runs the risk of being relegated to the judicial morass of "failed start" decisions such as Askov."

Significantly, Alberta is embarking on a process of amending its Rules of Court to restrict and limit discovery rights in civil proceedings. The issues and problems that arise in the context of disclosure in criminal law serve to provide feedback and insights into some of the serious risks that will manifest as the Alberta amendments become effective. Members of the Bar and any law reform commission or rules committee considering such amendments would do well to pay heed to the issues and problems arising in the current criminal disclosure procedure to assess the advisability of continuing with the amendments or further restricting discovery rights.

\section{BACKGROUND: R. V. STINCHCOMBE}

The criminal charges against William B. Stinchcombe were commenced with the swearing of an information on 16 March $1988 .^{8}$ The charges alleged thirteen counts of criminal breach of trust and thirteen counts of theft in relation to one complainant, Jack Abrams, and one charge of fraud in relation to a second complainant, Jerry Schwartz. Central to the charges was the relationship between Stinchcombe and Abrams. ${ }^{9}$ Stinchcombe was a solicitor practicing in Calgary. In 1974, he began acting for the complainant, Abrams. Between 1974 and 1980, the work performed by Stinchcombe was largely of a routine corporate and commercial nature. In 1980, however, a new relationship developed between the two men; at that time, Abrams had Stinchcombe take over the handling of a significant portion of Abrams' business affairs.

As part of the new arrangement, Stinchcombe and Abrams entered into a trust agreement whereby Stinchcombe purported to hold various assets belonging to Abrams, including shares in various Alberta and Texas corporations, as trustee for the benefit of Abrams. ${ }^{10}$ Various trust agreements were executed in relation to the assets and business affairs of Abrams, all of which purported to have the assets or shares held in trust by Stinchcombe for the benefit of Abrams." Following the transfer of the assets and shares, Stinchcombe began operating the businesses and investing the assets that had been transferred to him.

The position taken by the Crown, which was supported by the evidence of Abrams, was that Stinchcombe, who held the shares and assets as a trustee, converted the assets

7

R. v. Askov, [1990] 2 S.C.R. 1199. which signalled a clear and principled approach to issues surrounding delay in criminal cases, has, in the view of the author, been rendered largely inconsequential and ineffective by subsequent judicial glosses on the principles enunciated therein. Information against W.B. Stinchcombe (sworn 16 March 1988).

The following summary is taken from the proceedings before, and Reasons for Judgment of, Brennan J. at Trial I. That trial culminated in Stinchcombe's conviction on 20 February 1989.

Trial 1, supra note 4.

lbid. 
to his own use and benefit, contrary to the terms of the trust agreements. In support of its case, the Crown adduced evidence, largely through the report of a chartered accountant who investigated the complaint against Stinchcombe on behalf of the Law Society of Alberta, ${ }^{12}$ that reflected that a large portion of the assets and shares in question appeared to have been used for Stinchcombe's personal purposes.

The defence that was advanced by Stinchcombe, clearly manifested in the crossexaminations conducted at the preliminary inquiry ${ }^{13}$ and in the evidence and examinations adduced and conducted on behalf of Stinchcombe at Trial 1, was that the relationship between Stinchcombe and Abrams was not a trusteeship, but rather a business partnership in which the accused and the complainant were equal partners. The position was advanced that the assets and shares that had been transferred to Stinchcombe had diminished in value as a result of various investments, to the detriment of the partnership as a whole, and that some assets were transferred to Stinchcombe to which he was entitled as a partner in the venture.

The key issue in the case, from the very commencement of the proceedings, was the nature and extent of Stinchcombe's proprietary interest in the assets and shares which had been transferred to him by Abrams. As a corollary, it became evident (particularly in the examination of Abrams and other witnesses, including a legal assistant employed by Stinchcombe) that a significant issue in the case was whether the trust agreements, which had been entered into by Abrams and Stinchcombe, were ever intended to be effective or had been revoked. Abrams' credibility was a central issue in the case, and most particularly in relation to the question of the intended effectiveness or revocation of the various trust agreements.

To understand the case, it is essential to understand the history leading up to the commencement of the criminal proceedings against Stinchcombe. Only four years after the transfer of the assets and shares to Stinchcombe, Abrams made an assignment in bankruptcy in November 1984. Later that month, Abrams provided a statement of affairs, under oath, and responded to various questions put to him by the trustee, relating to his assets and business interests. ${ }^{14}$ Abrams then received an absolute discharge from bankruptcy less than five months later, in April 1985, which ended any financial liability of Abrams to the date of the discharge.

Only eight months after his absolute discharge from bankruptcy, in December 1985, Abrams issued a written complaint to the Law Society of Alberta against Stinchcombe. The complaint included a claim against the Assurance Fund of the Law Society of Alberta for an accounting and compensation for Stinchcombe's handling of the assets held by Stinchcombe in trust for Abrams. ${ }^{\text {is }}$ 
The connection between the bankruptcy proceedings involving Abrams and the Assurance Fund claim (involving the alleged fraud perpetrated by Stinchcombe against Abrams) was not lost on the Law Society investigators, as set out in an internal Law Society memorandum in April 1986: "if Mr. Abrams' claim against [Stinchcombe] has any substantial validity, then his bankruptcy may involve some substantial degree of fraud." 16

The memorandum (or the fact of the possible connection between the two proceedings) was not disclosed to Stinchcombe or his counsel until Trial 3, almost ten years after the memorandum was written.

In support of the complaint against Stinchcombe and as part of the claim against the Assurance Fund, Abrams also swore a statutory declaration (dated 22 May 1986, just over one year following his absolute discharge from bankruptcy) that indicated that Abrams was the alleged beneficial owner of certain Alberta and Texas corporations and, further, disclosing that various assets, including West Coast Transmission Debentures and Canada Savings Bonds, had been left with Stinchcombe for "safe keeping." 17 In addition to the complaint and Assurance Fund claim, Abrams also initiated a complaint alleging theft against Stinchcombe with the Commercial Crimes division of the Royal Canadian Mounted Police (R.C.M.P.) in June $1986 .{ }^{18}$ Interestingly, on 21 August 1986 , the officer in charge of the R.C.M.P. investigation, Sergeant White, met with the Law Society investigator, Jim McLeod, to discuss the allegations against Stinchcombe arising in the Law Society and criminal proceedings. ${ }^{19}$ Not surprisingly, on 17 September 1986, Sergeant White swore an Information to obtain a search warrant for the materials in the possession of the Law Society of Alberta and elsewhere. ${ }^{20}$ As indicated above, charges were initiated against Stinchcombe in March 1988. ${ }^{21}$

\section{A. Trial 1}

Within the above factual matrix, Trial 1 commenced in February 1989. For disclosure purposes, the most interesting facet of Trial 1, which resulted in the Supreme Court of Canada decision in Stinchcombe, relates to the evidence given by Stinchcombe's legal assistant at the preliminary inquiry. The Supreme Court described this evidence as "apparently, very favourable to the defence regarding the conduct of Abrams." 22 To understand the rest of the story, the nature of the evidence given by the legal assistant requires some elaboration. The essence of her evidence, taken at the preliminary inquiry, was that she typed a document and witnessed its execution by the complainant, Abrams. The document stated that Abrams expressly released Stinchcombe "from all Trust Agreements covering the shares of J.A.Y Resources Ltd."

Trial 3, supra note 4 (Evidence, Internal Law Society memorandum, dated 4 April 1986). Ibid. (Evidence, Statutory Declaration of Jack Abrams, dated 22 May 1986).

Officer's Notes, R.C.M.P. (Commercial Crimes) (6 June 1986).

Officer's Notes, R.C.M.P. (Commercial Crimes) (21 August 1986).

Information to Obtain Search Warrant (sworn 17 September 1986).

Supra note 8

Stinchcombe, supra note 1 at 330. 
(one of Abrams' corporations). ${ }^{23}$ As such, the legal assistant's evidence went directly to the heart of Stinchcombe's proprietary interest in a significant portion of the shares and assets of the complainant and, further, went to the issue of the effectiveness of the trust agreements and whether or not they were revoked.

As we know from the Supreme Court of Canada's decision in Stinchcombe, the Crown, through the R.C.M.P., conducted at least two further interviews of the legal assistant following the preliminary inquiry. ${ }^{24}$ The fact, but not the content, of those interviews was disclosed to counsel for Stinchcombe at Trial 1 when the Crown took the position that he would not be calling the legal assistant. In his view, given what was disclosed in the statements, she was not credible. Without having any knowledge of the contents of the statements that had been taken from the witness, and in the face of the Crown's submission that she was not worthy of credit, counsel for Stinchcombe (after applying for disclosure of the statements, or for an order by the Court directing that the witness be called by the Crown, or for the Court to call the witness itself, all of which had been refused by the presiding trial judge) elected not to call the legal assistant at Trial 1.

The history and content of the statements taken from the legal assistant, following the preliminary inquiry, are themselves significant. The statements included an extensive tape-recorded interview of the legal assistant, conducted by the R.C.M.P. following the preliminary inquiry, in which the legal assistant was extensively examined, re-examined and cross-examined on whether or not she could have witnessed the complainant executing the release from trust which she indicated she had typed. ${ }^{25}$ The thrust of the interview, the text and content of which was not provided to the defence until the proceedings leading up to Trial 2 , was that the investigators did not believe the legal assistant and that she must have been mistaken in her evidence given at the preliminary inquiry. Not surprisingly, and notwithstanding that she had given evidence which clearly indicated that she had witnessed the signature of Abrams on the subject document, subsequent to the interviews with the R.C.M.P., the legal assistant retreated to the position that she may not have accurately recalled whether or not she witnessed the complainant signing the subject document.

The tape-recorded statement was taken in October 1988. In February 1989, the R.C.M.P. took a further statement from the legal assistant, this time in writing and signed by her, which stated as follows: "after my testimony at the Preliminary [Inquiry] of the Trial of Bill Stinchcombe I have reflected on my testimony and there are some areas that are incorrect." 26

As one reviews the flow of the recorded interview and the subsequent written statement, one sees that the legal assistant changes her position considerably. At the 
preliminary inquiry, she was able to directly respond to questions. ${ }^{27}$ After several suggestions by the R.C.M.P. officers that she would not want to "perjure" herself and that she should "not bring [herself] any further into this thing than [she] already [was]," ${ }^{28}$ she stated that she was "mistaken" in her earlier testimony. The R.C.M.P. then told her to "get a hold of herself," ${ }^{29}$ and put this suggestion to her:

I mean you, at. at this particular point I would suggest that you look after yourself. You're number, you're number one as far as this whole thing goes in your own mind and I wouldn't protect anybody, especially when you're involved more deeply than, you're now involved more, much more deeply through, through the whole situation than you should have been. When you analyze the whole thing I, I would look out for, for yourself at this particular point in time. And you'd better clear your mind and, I mean, it comes down to whether you actually knew that you should remember that document or not when you got on the stand and from what you've told us you don't really remember the thing. ${ }^{30}$

The legal assistant, after pleading with the officers to "just discredit [her] testimony," 31 then stated that, notwithstanding that she had been positive about her evidence at the time of the preliminary inquiry, she was no longer certain. ${ }^{32}$ To conclude the decimation of the legal assistant as a potential witness, the police obtained a written statement from her that provided the following: "the document that was presented at the Preliminary Enquiry [sic] and unsigned dated 1 Aug 1981 was not typed by me and that particular document I did not see Jack Abrams sign it." ${ }^{33}$

Stinchcombe was convicted at Trial 1 on 20 February 1989 and sentenced to nine years' incarceration. The Alberta Court of Appeal, after hearing argument on various issues, including issues relating to the non-disclosure of the subject statements, dismissed the appeal without reasons. ${ }^{34}$

The decision of the Supreme Court of Canada, on appeal from Trial 1, is a decision with which virtually every lawyer in Canada is familiar. ${ }^{35}$ In relation to the subject statements, it is worth noting that no effort was made to provide the statements to Stinchcombe's counsel prior to the Supreme Court hearing, except for an informal offer to permit counsel to see them made, without notice, during the Court of Appeal hearing. During the hearing before the Supreme Court of Canada, however, and only after having heard the argument of counsel for Stinchcombe, the Crown did offer to disclose those parts of the subject statements that were available to the Crown at the time. ${ }^{36}$ The Supreme Court of Canada declined the Crown's offer made, as it was, at

\footnotetext{
27 Trial 2, supra note 4 (Evidence. Exhibit 6. Interview with P. Hunt (27 October 1988) at 3).

$2 \times \quad$ Ibid. at 8 .

Ibid. at 20

w) Ibid. at 22

"Ibid.

$12 \quad$ Ibid. at 25

$"$ Trial 2, supra note 4 (Evidence, Exhibit 2. Statement of Patricia Hunt (7 February 1989) at 1).

"4. $\quad$ v. Stinchcombe (10 April 1990), Calgary 10875 (Alta. C.A.).

is Stinchcombe, supra note 1.

ห. $\quad$ Stinchcombe v. The Queen (2 May 1991) 21904, Transcript of Proceedings at 29 (S.C.C.).
} 
such a late stage in the proceedings and without any pre-hearing notice to Stinchcombe or his counsel. ${ }^{37}$

A central issue that developed during the course of the argument before the Supreme Court was what use, if any, trial counsel could have made of the subject statements had they been disclosed to him. In a significant interchange with the Court, counsel for Stinchcombe, William Code, responded to a suggestion that trial counsel could simply have called the witness by stating as follows:

it would be a very negligent thing, in my view, [for] counsel to be calling a witness when he knows the other side have a statement and the other side have told them that the statement makes this witness incredible. If we called that witness as our own witness, that would be negligent. ${ }^{38}$

Code's submission, and the remedy granted by the Supreme Court of Canada, were all made without knowledge of the contents of the subject statements. Given the information available to trial counsel, the Court was prepared to assume "that nonproduction of the statements was an important factor in the decision not to call the witness." 39

In relation to the subject statements, the Court ordered that "Examination of the statements, which were tendered as fresh evidence in this Court, should be carried out at trial so that counsel for the defence, in the context of the issues in the case and the other evidence, can explain what use might be made of them by the defence." ${ }^{" 40}$ In the circumstances, and without having reviewed the non-disclosed statements, the Supreme Court of Canada allowed the appeal and ordered a new trial.

Members of the Bar are familiar with the general principles of the Supreme Court's decision in Stinchcombe and a detailed review of them is unnecessary. For the purpose of this article, however, there are two key elements of the decision upon which emphasis should be placed. The first deals with the paradigm for discovery of documents that was borrowed from civil procedure in Sopinka J.'s judgment. Speaking for a unanimous court, Sopinka J. set the stage for the broad disclosure principles he would adopt later in his reasons:

Production and discovery were foreign to the adversary process of adjudication in its earlier history when the element of surprise was one of the accepted weapons in the arsenal of the adversaries. This applied to both criminal and civil proceedings. Significantly, in civil proceedings this aspect of the adversary process has long since disappeared, and full discovery of documents and oral examination of parties and even witnesses are familiar features of the practice. This change resulted from acceptance of the principle that justice was better served when the element of surprise was eliminated from the trial and the parties were prepared to address issues on the basis of complete information of

Ibid. at 31-32, 48-51.

Stinchcombe, supra note I (Transcript of Proceedings (2 May 1991) at 7).

Stinchcombe, supra note 1 at $348 \mathrm{ff}$.

Ibid. 
the case to be met. Surprisingly, in criminal cases in which the liberty of the subject is usually at stake, this aspect of the adversary system has lingered on. ${ }^{41}$

Then, after noting that "the fruits of the investigation ... are not the property of the Crown for use in securing a conviction but the property of the public to be used to ensure that justice is done," 42 Sopinka J. reviewed the scope of relevance and, again borrowing from civil practice, stated

A discretion must also be exercised with respect to the relevance of information. While the Crown must err on the side of inclusion, it need not produce what is clearly irrelevant. The experience to be gained from the civil side of the practice is that counsel, as officers of the court and acting responsibly. can be relied upon not to withhold pertinent information. Transgressions with respect to this duty constitute a very serious breach of legal ethics. The initial obligation to separate "the wheat from the chaff' must therefore rest with Crown counsel. ${ }^{43}$

\section{B. Trial 2}

Subsequent to the Supreme Court's decision in Stinchcombe, on 23 July 1992, the defence requested that the Crown produce the statements which the Court had ordered produced, as well as the police officer's notes. ${ }^{44}$ On 17 August 1992, the Crown advised the defence that it had been unable to locate the tape recording of the October 1988 interview of the legal assistant. ${ }^{45}$ Further, on 30 September 1992, the Crown advised that it had been unable to locate the tape or tapes of the interview or the original handwritten statement. ${ }^{46}$ At no time prior to the commencement of Trial 2 did the Crown provide any disclosure with respect to the bankruptcy of Abrams.

Trial 2 commenced with an application by Stinchcombe, through his new trial counsel Ross Mitchell, for a stay of proceedings given the failure of the Crown to produce the statements which the Supreme Court had ordered produced. Upon hearing submissions from the defence and the Crown, Waite J., the presiding trial justice at Trial 2, entered a judicial stay of proceedings on 6 October 1992.

The second phase, and the factual circumstances of the appeals to the Alberta Court of Appeal and the Supreme Court of Canada, are largely unknown to the Bar. The officer involved in the investigation of the original complaint against Stinchcombe had died prior to the Supreme Court's decision in Stinchcombe in 1991, but following the appeal to the Court of Appeal. Efforts had been made to locate the subject statements in his personal effects, but to no avail. At the time of the application to adduce the statements in Stinchcombe, the Crown did not have the original statements, but only the officer's notes and a Crown prosecutor's recollection of his interview of the legal assistant during the proceedings leading to Trial 1 . 
It appears that, even though the legal assistant's statements were in issue in the appeal to the Court of Appeal from Trial 1, the Crown had failed to obtain possession (or require the securing) of the original subject statements. As a result, the death of the investigator meant that the location of the statements was unknown to the Crown or police.

The Alberta Court of Appeal overturned the judicial stay of proceedings which had been entered by Waite $\mathrm{J}^{47}$ On appeal as of right, to the Supreme Court of Canada, ${ }^{48}$ the Court adopted the reasons for judgment of the Alberta Court of Appeal and, in response to the Crown's explanation for the non-production of the subject statements, concluded as follows:

\begin{abstract}
The Crown can only produce what is in its possession or control. There is no absolute right to have originals produced. If the Crown has the originals of documents which ought to be produced, it should either produce them or allow them to be inspected. If, however, the originals are not available and if they had been in the Crown's possession, then it should explain their absence. If the explanation is satisfactory, the Crown has discharged its obligation unless the conduct which resulted in the absence or loss of the original is in itself such that it may warrant a remedy under the Canadian Charter of Rights and Freedoms. ${ }^{49}$
\end{abstract}

In the result, the Supreme Court of Canada in Stinchcombe No. 2 affirmed the decision of the Alberta Court of Appeal and ordered a new trial - Trial 3.

Somewhat surprisingly, neither the decision of the Alberta Court of Appeal ${ }^{50}$ nor that of the Supreme Court in Stinchcombe No. 2 addressed certain key findings made by Waite J., the presiding trial justice. He had specifically held that, while the subject statements "were known to be in [the investigator's] possession during the course of the trial in February 1989," and had formed one of the grounds of appeal before the Alberta Court of Appeal immediately following Trial 1, the Crown did not comply with the direction of the Supreme Court of Canada in Stinchcombe No. 2. ${ }^{51}$ Further, in Waite J.'s review of the submissions with respect to the prejudice arising from the nondisclosure of the original tape-recorded statement, he stated,

See $R$. v. Stinchcombe (1994), 149 A.R. 167 (C.A.).

The appeal was as of right because the trial had resulted in an effective acquittal, which had been overturned by the Court of Appeal.

Stinchcombe No. 2, supra note 5 at 2 [emphasis added]. This aspect of Stinchcombe No. 2 was taken up, again, by the Supreme Court of Canada in R. v. La, [1997] 2 S.C.R. 680 at para. 20. Sopinka J., for the majority, stated that

despite the best efforts of the Crown to preserve evidence, owing to the frailties of human nature, evidence will occasionally be lost. The principal in Stinchcombe (No. 2), supra, recognizes this unfortunate fact. Where the Crown's explanation satisfies the trial judge that the evidence has not been destroyed or lost owing to unacceptable negligence, the duty to disclose has not been breached. Where the Crown is unable to satisfy the judge in this regard, it has failed to meet its disclosure obligations, and there has accordingly been a breach of $\mathbf{s .} 7$ of the Charter. Such a failure may also suggest that an abuse of process has occurred, but that is a separate question. It is not necessary that an accused establish abuse of process for the Crown to have failed to meet its $\mathbf{5 .} 7$ obligation to disclose.

Supra note 47.

Trial 2, supra note 4 at 80. 
There is a further serious aspect to the loss of the tape itself. Gone forever is that [characteristic] which makes the taping of interviews so preferable. That is that the atmosphere of the interview is captured on tape. The inflections, hesitations, tensions, emotional states and attitudes are recorded. The transcript cannot convey that atmosphere, although in this case one transcript does allude to the fact, at one point in the interview, that the witness is crying. The general atmosphere is lost. ${ }^{52}$

In conclusion, in granting a stay of proceedings, the presiding trial justice found that "the prosecutorial authorities have put it beyond their power to comply with the direction of the Supreme Court of Canada." 53

The Alberta Court of Appeal did not address the substance of the prejudice that had been identified by Waite J., but instead focused on the issues surrounding authentication of the statements for the purpose of admission in evidence at trial. ${ }^{54}$ Furthermore, the Supreme Court of Canada did not take up a specific assessment of the prejudice that had been identified by Waite J. either, but, rather, adopted the decision of the Alberta Court of Appeal and simply addressed the issues surrounding the explanation for the absence of the original statements. ${ }^{55}$

It is likely that the actual explanation for both the Alberta Court of Appeal and the Supreme Court of Canada's avoidance of a direct analysis of Waite J.'s decision rests on the fact that, as stated by the Alberta Court of Appeal, "the original tape and the original handwritten statement were discovered by the widow of [the investigator] subsequent to the decision appealed from and are again in the hands of the police." Although the Courts did not say so, it is clear that any perceived prejudice on the record before Waite J. would be discharged on the hearing of a new trial, given that the original statements were now within the Crown's possession and available for disclosure.

\section{TRIAL 3}

Notwithstanding the unusual history surrounding the statements given by the legal assistant - statements which were the subject of Stinchcombe and Stinchcombe No. 2 - perhaps the most interesting and illustrative aspect of the disclosure issues that arose in the case against Stinchcombe evolved following the order for a new trial in Stinchcombe No. 2 and leading up to Trial 3. Prior to the Supreme Court's decision in Stinchcombe No. 2, and notwithstanding the decision in Stinchcombe, the Crown had provided little in the way of additional disclosure to either Stinchcombe or his counsel (other than addressing the specific issues that arose in relation to the statements given by the legal assistant). ${ }^{57}$

$52 \quad$ Ibid. at 82 .

s3 Ibid.

ss $\quad$ Stinchcombe No. 2 (C.A.), supra note 47.

ss Stinchcombe No. 2, supra note 5 at 31-32.

s6. Stinchcombe No. 2 (C.A.), supra note 47 at 40.

37 Note that the broad duty to disclose relevant evidence had been further elaborated upon by the Supreme Court of Canada in R. v. Egger, [1993] 2 S.C.R. 451 [hereinafter Egger], even before the hearing of Stinchcombe No. 2, and further, that the Supreme Court of Canada had released its decision in $R$ v. Chaplin, [1995] I S.C.R. 727 [hereinafter Chaplin] well before the 
In a process that has become all too common in criminal cases, the causes for which will be analyzed and critiqued later in this article, counsel for Stinchcombe, Ross Mitchell, began the work of prying additional, relevant disclosure from the Crown through extensive and detailed correspondence and the retention of a private investigator. The effort undertaken by Mitchell was, in effect, an attempt to police and enforce the Crown's obligation to produce all relevant documentation relating to the prosecution against Stinchcombe. Notwithstanding the Crown's obligation, which has been characterized as one of "utmost good faith," not forthcoming until specific demands were made through no less than twelve letters from defence counsel demanding production of specific pieces. ${ }^{59}$

Significantly, the Crown advised as late as 5 February 1996 (less than one month prior to the scheduled commencement of Trial 3) that "defence counsel have received full disclosure." ${ }^{100}$ Following that letter (and recalling that an order for a new trial had been issued in Stinchcombe No. 2 on 23 February 1995, nearly twelve months earlier) no less than ten further disclosure packages were provided to counsel for the defence in the month preceding the commencement of Trial 3. The disclosure provided in that period included "will say" statements of additional witnesses to be called at trial, transcripts of interviews with the chartered accountant retained by the Law Society of Alberta who would be giving evidence in relation to the central accounting issues, and related investigators' notes, and finally, documentation relating to the bankruptcy proceedings involving Abrams.

It is particularly significant to note that, notwithstanding the duty to act in utmost good faith imposed upon the Crown, the materials relating to the bankruptcy of Abrams were not disclosed to the defence until the defence had retained a private investigator. The investigator uncovered the fact of a bankruptcy investigation, undertaken in relation to the bankruptcy proceedings of Abrams, which followed Abrams giving evidence at the preliminary inquiry. As indicated earlier in this article, the connection between the bankruptcy proceedings involving Abrams and the criminal proceedings and Assurance Fund claims had been recognized by both the Law Society investigator and R.C.M.P. well before Trial $1,^{61}$ but no effort had been made to disclose any aspect of that investigation (or even the existence of such an investigation) until just before Trial 3.

What was disclosed to the defence in the one-month period preceding the commencement of Trial 3 was that, following the evidence given by Abrams at the preliminary inquiry, the trustee in bankruptcy for Abrams had requested an investigation into potential fraud in relation to the bankruptcy proceedings. ${ }^{62}$ It appeared that such an investigation was in fact commenced by the R.C.M.P. ${ }^{63}$ In addition, the statutory

commencement of Trial 3 in March 1996.

R. v. Chaplin, ibid. at para. 21.

Letters from R. Mitchell to Special Prosecutions (23, 27, 29 July 1992; 15, 26 February 1996; 6

March 1996).

Letter from Crown Prosecutor to Defence Counsel (5 February 1996).

Supra note 4.

Letter from Special Prosecutions to R. Mitchell (27 February 1996).

lbid. 
declaration given by Abrams to the Law Society of Alberta was finally disclosed to the defence; it indicated that Abrams asserted an ownership interest in the various assets and shares held by Stinchcombe. ${ }^{64}$

There is a contradiction between the statutory declaration provided to the Law Society of Alberta and the November 1984 statement of affairs, also given under oath by Abrams. ${ }^{65}$ The two statements were taken only 17 months apart, and the latter (which asserted an ownership interest in the assets held by Stinchcombe) was given only after Abrams received an absolute discharge from bankruptcy.

Further, and most significantly, on 13 March 1996, one week following the date upon which Trial 3 was originally scheduled to commence, a memorandum to file from the Crown prosecutor on Trial 1 was disclosed to the defence for the first time. This memorandum detailed particular issues that had arisen following Abrams' evidence given at the preliminary inquiry. ${ }^{66}$

The 10 August 1988 Crown memorandum indicated that, following his giving of evidence at the preliminary inquiry, Abrams attended at his own lawyer's office. His lawyer then contacted the Crown prosecutor and indicated that Abrams had expressed concern that he had lied. As indicated in the memorandum, "it appears that Mr. Abrams was upset because he had lied, but it was not clear to [the Crown prosecutor] from the subsequent discussion with [Abrams' counsel] whether Mr. Abrams was speaking about having lied when he made his Assignment in Bankruptcy in November 1984 or about lying in testifying at the Preliminary Inquiry August 8, 1988."

The concern expressed in the Crown memorandum related to whether Abrams disclosed to the trustee in bankruptcy whether he had any interest in J.A.Y. Resources, Alberta Investments, Canada Savings Bonds, or West Coast Transmission Debentures; at that time he was asserting that he had such interests for the purposes of the criminal proceedings and the Assurance Fund claim. At no time prior to March 1996 was it ever disclosed to the defence that Abrams had been investigated for bankruptcy fraud or that he had, through his counsel, indicated to the Crown Prosecutor that he had "lied."68

Curiously, in Trial 1, the Crown prosecutor had advised the Court that the legal assistant would not be called as a Crown witness because she was "not worthy of credit" given her statements to the investigators. ${ }^{69}$ Notwithstanding the position taken relative to the legal assistant, Abrams had been tendered as a Crown witness in that same trial even though the Crown was aware of contradictory sworn statements given by him and, further, was aware that Abrams had expressed concern about having lied.

Trial 3, supra note 4 (Evidence adduced in voir dire I).

Ibid.

The Crown prosecutor's memorandum, dated 10 August 1988, was not adduced in evidence during Trial 3; however, it was put in evidence and referenced by the Alberta Court of Appeal in Stinchcombe v. Law Society of Alberta (2002), 303 A.R. 67 (C.A.).

Ibid. (Evidence. Crown Memorandum to File) at I.

Ibid.

Trial 1. supra note 4 at $265 f$ f. 
After several adjournments, Trial 3 commenced on 22 March 1996. At that time, the Crown prosecutor, who was not the prosecutor for either of the previous trials, reviewed with the Court some of the circumstances surrounding the fact of timely disclosure "not being made to the defence." He concluded that, "when considered against the backdrop of the history of this case ... [the Crown has] great concern as to whether Mr. Stinchcombe can now have a fair trial." ${ }^{\text {70 }}$ In relation to the connection between the bankruptcy proceedings and the criminal charges, the Crown prosecutor indicated as follows:

Your Lordship has also heard evidence concerning a bankruptcy investigation against Mr. Abrams that was conducted by the RCMP between the preliminary hearing and the first trial. The file was concluded in 1989 with no charges being laid. In accordance with RCMP policy, tapes of the statements taken from Abrams were then destroyed. One of the two statements was never transcribed and is now unavailable. It did not occur to the investigator at the first trial that this material should be disclosed to the defence. The Crown has concluded that the existence of this file and the statements taken from Mr. Abrams should, based on the present state of the law, have been disclosed before the first trial. ${ }^{71}$

Further, in relation to the 10 August 1988 Crown prosecutor memorandum, ${ }^{72}$ the Crown indicated the following:

\begin{abstract}
After this memorandum was discussed at our office and after considering the contents of the memorandum and the potential effect of Mr. Abrams' solicitor/client privilege, it became clear that this memorandum should have been disclosed to the defence before the first trial. It contains information which may have given rise to another avenue of attack on the credibility of the chief crown witness. This avenue is no longer available due to the effect the passage of time has had on the recollection of those involved. An interview last week with Mr. Abrams' counsel confirmed this to be the case. ${ }^{73}$
\end{abstract}

In conclusion, the Crown prosecutor stated that "the ability of the accused to make full answer and defence has been seriously affected by the passage of time, the history of this case and current disclosure difficulties. It is, therefore, the Crown's intention to call no evidence ... and invite the Court to acquit the accused of all charges."74

In the result, no evidence having been adduced, Stinchcombe was acquitted of all charges. The acquittal was entered just short of ten years following the original complaint to the R.C.M.P. by Abrams.

\title{
D. The End OF THE StORY - Administrative Proceedings
}

William Stinchcombe's involvement with the courts on disclosure issues did not end with his acquittal at Trial 3. As indicated earlier in this article, in April 2002 a decision of the Alberta Court of Appeal was released in which the Court considered the tragic

Trial 3, supra note 4 (oral argument, Crown prosecutor at 2-3).

Ibid. at 3-4.

Supra note 67.

Trial 3. supra note 4 at 4-5.

lbid. 
and convoluted history of Stinchcombe's suspension by the Law Society of Alberta. ${ }^{75}$ In the end, the Court of Appeal found that, as a result of significant delays and a failure to make adequate disclosure, the Investigating Committee's decision to stay the proceedings against Stinchcombe only in relation to the complainant Abrams - and not in relation to the complainant Schwartz - should be overturned. As a result, all complaints, which permitted the suspension of Stinchcombe, were subject to a stay of proceedings and, in effect, Stinchcombe was reinstated as a member in good standing of the Law Society of Alberta.

The issue with respect to the delays surrounding Stinchcombe's suspension related to the fact that Stinchcombe had been suspended without a hearing since September 1987 through to April 2002. An Investigating Committee had been established by the Law Society of Alberta to determine what position the Law Society would take with respect to the suspension. The Committee had concluded that "the destroyed RCMP tapes, together with the undisclosed Crown memorandum throwing doubt on Abrams' veracity and the inability of Abrams' lawyer to remember his conversations with Abrams and the prosecutor, constituted prejudice to Stinchcombe's ability to defend the Abrams charges." 76

The Committee had, however, declined to find prejudice in relation to Stinchcombe's ability to defend the Schwartz charges. ${ }^{77}$ An application for judicial review to the Court of Queen's Bench of Alberta was denied, for the reasons set out by the Committee. ${ }^{78}$ On appeal to the Alberta Court of Appeal, however, the Court found that the relationship between Abrams and Stinchcombe was "inextricably linked to the Schwartz charges." 79 The Court of Appeal found that, among other things, the documents and information which were either not disclosed ${ }^{80}$ or which were disclosed too late in the proceedings ${ }^{81}$ combined to cause Stinchcombe significant prejudice in his ability to defend the charges brought by the Law Society of Alberta if the hearing was now to be considered.

\section{The Court of Appeal concluded that}

Knowledge of the case one has to meet is but one aspect of prejudice. The question is whether the ability to meet that case has been prejudiced by the delay. Stinchcombe argues that lost documents, destroyed tapes of police interviews with Abrams, the lost memory of Abrams' lawyer, deceased and lost witnesses and dimmed memories, individually and collectively, seriously prejudice his capacity to answer the Schwartz charges.

The Committee correctly concluded that the destroyed RCMP tapes and the lost memory of Abrams' lawyer are losses that irreparably damaged Stinchcombe's ability to challenge Abrams' credibility as

Supra note 6.

Ibid. at para. 19.

lbid. at para. 20.

lbid. at paras. 21-23.

lbid. at para. 27.

That is, documents relating to the bankruptcy investigation which were destroyed by the R.C.M.P.

That is, the Crown prosecutor's memorandum dated 10 August 1988, supra note 66 . 
a witness. It found that the lost and unavailable evidence prejudiced Stinchcombe with respect to the Abrams charges. ${ }^{82}$

Given that the Abrams charges were inextricably linked to the Schwartz charge, the Court of Appeal entered a stay of all proceedings against Stinchcombe.

The Alberta Court of Appeal decision hopefully concludes Stinchcombe's convoluted journey through the criminal justice and administrative law processes. Stinchcombe's involvement with the courts and the Law Society of Alberta, as will be discussed herein, creates a backdrop for a consideration of the issues raised in this issue of the Alberta Law Review. These include the applicability of Stinchcombe to the administrative process, the duty and role of the Crown prosecutor, issues relating to disclosure by the defence and issues relating to third-party disclosure. For the purposes of the present article, however, the tragic disclosure history manifested in the proceedings against Stinchcombe will be assessed against the vision of Sopinka J. in Stinchcombe, which attempted to adopt the paradigm of the civil discovery process for the purposes of criminal proceedings. It will be argued, through the remainder of this article, that taking Sopinka J. seriously in relation to the civil discovery paradigm would be of great assistance in resolving some of the problems which have developed with the Court's application of the principles articulated in Stinchcombe.

\section{The Civil Discovery Paradigm - A Failed Model}

The history of the prosecution against Stinchcombe, while an interesting story in its own right, has been set out to provide a backdrop for a discussion of the failure of the Courts to take seriously the insights from Sopinka J.'s decision in Stinchcombe. The essence of Stinchcombe is found in the suggestion that criminal procedure needs to adopt the model of pretrial discovery found in civil procedure. According to Sopinka J., the adoption of the civil procedure discovery model is necessary because "justice [is] better served when the element of surprise [is] eliminated from the trial and the parties [are] prepared to address issues on the basis of complete information of the case to be met." ${ }^{\text {"83 }}$

By adopting the civil discovery paradigm, Sopinka J. suggests that the "experience to be gained from the civil side of the practice is that counsel, as officers of the court and acting responsibly, can be relied upon not to withhold pertinent information." 84 Having placed faith in Crown prosecutors and defence counsel to act responsibly in the discovery process, Sopinka J. then states his confidence that "disputes over disclosure will arise infrequently."

Sadly, as the story of the prosecution against Stinchcombe illustrates, issues in relation to disclosure do arise and, indeed, arise frequently. Even simple searches of the online databases demonstrate the frequency with which Stinchcombe is cited in the 
context of disputes over disclosure in criminal proceedings. This frequent citation in a criminal context is in sharp contrast to the relatively infrequent number of decisions that relate to the document production sections of the various Rules of Court. ${ }^{86}$ The issues to be addressed in this section are whether or not Sopinka J.'s "faith" ${ }^{\text {" } 7}$ was misplaced and whether, in fact, the paradigm of civil pretrial discovery has ever been fully adopted.

The most significant element of the history of the Stinchcombe prosecution relates to the efforts expended by defence counsel in securing disclosure of various materials - materials which, in the end, were highly significant to both the prosecution and defence, and resulted in the Crown adducing no evidence in Trial 3 . The efforts of defence counsel, while admirable, entailed a significant amount of effort including extensive correspondence and the retention of a private investigator. These measures were required to extract from the Crown certain documents which, even to the original police investigators, were clearly relevant and connected to the prosecution and defence. ${ }^{88}$ Notwithstanding the Supreme Court's decision in Stinchcombe, in the new trial ordered by that Court the same prosecutors failed to comply with the disclosure obligation and necessitated the expenditure of resources and time by the defence to enforce the duty.

Three aspects to the disclosure obligation will be reviewed herein to demonstrate the failure of the courts to properly adopt the model of civil discovery and explain the frequent disputes over disclosure in criminal proceedings. The issues that will be addressed relate to the determination of what is "relevant," 89 the expectation of the Courts that defence counsel will police prosecutors' compliance with the obligation and, intimately connected with the latter issue, the remedies or sanctions that have been imposed where the prosecution has failed to comply with the disclosure obligation.

Even though the Supreme Court of Canada connected the discovery model for criminal proceedings with the civil discovery process, little analysis of or reference to civil process can be found in subsequent disclosure authorities, even at the Supreme Court of Canada level. As will be demonstrated herein, an analysis of the key components of the civil discovery model reveals the failure of the subsequent authorities to achieve effective disclosure rules, particularly in relation to the three areas identified above. Returning to the roots of civil discovery procedure, as understood and envisioned by Sopinka J., suggests, in my opinion, the direction in which the courts

*. For example, an annotation of Stinchcombe, supra note 1, yields 162 hits in the Alberta eCarswell database; an annotation of Czuy v. Mitchell (1976). 72 D.L.R. (3d) 424 (Alta. C.A.) (the leading Alberta decision on the scope of pretrial civil discovery) yields 55 hits. Clearly, the number of hits may be distinguishable on any number of grounds and a more accurate measure found; but, based upon this author's experience in both civil and criminal proceedings, issues surrounding disclosure in criminal matters arise far more frequently than in civil proceedings. This differential is especially relevant to the disclosure of documents. Counsel are invited to consider whether their own experiences reflect a similar pattern.

*7 Stinchcombe, supra note 1 .

xx See, e.g., Trial 3, supra note 4 (Evidence, Exhibit 13. Memorandum by J. McLeod (8 April 1986) and Evidence. Exhibit 7. Internal Law Society Memorandum by T. Mayson (4 April 1986)).

8y As discussed by Sopinka J. in Stinchcombe, supra note 1 at 339. 
must move to rectify the failings present in the current state of pretrial criminal disclosure.

Of the three aspects identified above, it is the interrelation of the definition of relevance and the remedies or sanctions applied in the event of a failure by the prosecution to comply with the disclosure obligation that has signalled the failure of the existing state of criminal pretrial disclosure. As discussed below, the definition of relevance, which depends on the Crown making judgments about what use the defence may make of the document, when combined with weak and infrequently imposed sanctions, or sanctions applied only in the most serious cases, results in little or no incentive for the defence to police and enforce the obligation. In fact, given the generally uncompensated costs and delays incurred by the defence in applying to remedy inadequate or failed disclosure, there is a strong disincentive for active policing of the prosecution. Without effective policing and enforcement, the constitutional right to criminal pretrial disclosure, as envisaged by Sopinka J., becomes hollow.

As discussed below, in developing the concept and meaning of relevance, subsequent decisions of the Supreme Court of Canada have focused, in large measure, on whether the document or information "may be useful to the defence." The courts, including the Court in Stinchcombe, place the obligation on the Crown prosecutor to make the original judgment as to whether any documents are relevant or of use to the defence. ${ }^{91}$ Such judgments are made in the absence of the accused or defence counsel, who may never know that particular documents or classes of documents were not considered useful and were therefore not produced. Since the prosecutor may not anticipate, appreciate or value the defences that may be advanced, there is a perpetual risk of disclosure failures. In Stinchcombe, the prosecutor's failure to apprehend the use to be made of the bankruptcy filing and investigation of the complainant demonstrates a crystallization of that risk.

Recognizing the role to be played by the prosecutor's judgment, the Supreme Court stated in Chaplin that "of necessity, great reliance must be placed on the integrity of the police and prosecution bar to act in the utmost good faith. It is for this reason that departures from this onerous obligation are treated as very serious breaches of professional ethics." 92

As will be argued herein, the effective adoption of the civil discovery paradigm for the purpose of criminal proceedings, as contemplated in Stinchcombe, requires a broader definition of the scope and manner of determination of what is relevant and therefore subject to disclosure, and enhancements to the remedies or sanctions that are applied in the face of a failure on the part of the Crown prosecutor to comply with the disclosure obligation. The failure of the courts to adopt such effective procedures reduces the central concepts of "utmost good faith" and "right to disclosure" to mere empty shibboleths. What remains unscathed is the potential for further failures in the disclosure process and the prospects of more Stinchcombes, Marshalls and Milgaards.

Egger, supra note 57 at 467, reiterated in Chaplin, supra note 57 at paras. 21-22.

See, e.g., Stinchcombe, supra note 1 at 335-36.

Chaplin, supra note 57 at para. 21 [emphasis added]. 


\section{A. Relevance}

Following Stinchcombe, two decisions were released by the Supreme Court that represented an attempt by the Court to elucidate the concept of relevance for the purposes of disclosure: Chaplin ${ }^{93}$ and Egger. ${ }^{94}$ To summarize the effect of these authorities, documents or information are relevant, and the duty to disclose is triggered, "whenever there is a reasonable possibility of the information being useful to the accused in making full answer and defence."

In Chaplin, the Supreme Court of Canada reaffirms its confidence, earlier expressed by Sopinka J. in Stinchcombe, in the role to be played by the Crown prosecutor:

The Crown obligation to disclose all relevant and non-privileged evidence, whether favourable or unfavourable, to the accused requires that the Crown exercise the utmost good faith in determining which information must be disclosed and in providing ongoing disclosure ... [o]f necessity, great reliance must be placed on the integrity of the police and prosecution bar to act in the utmost good faith. It is for this reason that departures from this onerous obligation are treated as very serious breaches of professional ethics. ${ }^{96}$

The Court in Chaplin then repeats and adopts the test for "relevance" that had previously been established by that Court in Egger. Egger had held that:

One measure of the relevance of information in the Crown's hands is its usefulness to the defence: if it is of some use, it is relevant and should be disclosed.... This requires a determination by the reviewing judge that production of the information can reasonably be used by the accused either in meeting the case for the Crown, advancing a defence or otherwise in making a decision which may affect the conduct of the defence such as, for example, whether to call evidence. ${ }^{97}$

It is significant to note the connection between the duty cast upon the Crown, characterized as being one of "utmost good faith," and the reliance placed upon the Crown prosecutor under this obligation to ascertain the documents and information which are relevant. This concept of "utmost good faith" is a concept borrowed from the law of fiduciary obligations, considered in such cases as Hodgkinson v. Simms. ${ }^{99}$ Similarly, the concept of "utmost good faith" appears in the insurance law context where the parties may be, effectively, at the mercy of one another:

A great deal has been made in the case law, to which this Court was referred, of the fact that insurers vis-d-vis their insureds are in a superior bargaining position and one which places the insureds in positions of dependency and vulnerability. Equally, insurers must not be looked upon as fair game. It

Ibid.

Egger, supra note 57.

R. v. Dixon (1998), 122 C.C.C. (3d) 1 at 21 (S.C.C.) [emphasis added] [hereinafter Dixon], in which Cory J. summarizes the effect of Egger, ibid. and Chaplin, supra note 57.

Chaplin, ibid. at para. 21 [emphasis added].

Egger, supra note 57 at 467.

Chaplin, supra note 57 at para. 21.

Hodgkinson v. Simms, [1994] 3 S.C.R. 377. 
is a two-way street founded upon the principle of utmost good faith arising from the very nature of the contract. Thus, it is appropriate that punitive damages be awarded..$^{100}$

Two concepts emerge: the Crown prosecutor is under the highest duty recognized in law to ensure that all relevant documents and information are disclosed and, in discharging that duty, the test to be applied in determining relevance is the usefulness of such documents or information to the defence in making full answer and defence.

The effectiveness of and risks inherent within the concept of "usefulness to the defence" were considered in the Royal Commission on the Donald Marshall, Jr. Prosecution, ${ }^{101}$ which report was specifically relied upon by the Supreme Court of Canada in Stinchcombe. ${ }^{102}$ Most significantly, the Commissioner specifically resiled from the notion that the determination of usefulness of documents or information could be made by the Crown prosecutor:

\begin{abstract}
The Crown prosecutor occupies a dual role, being obligated on the one hand to prosecute vigorously those accused of crime, and on the other hand to ensure that the power of the State is used only in the pursuit of impartial justice. But it is not realistic to believe that the prosecutor does not have an interest in the outcome of a criminal trial. To expect any prosecutor to evaluate with any degree of objectivity whether certain evidence in his or her possession will be of use to the accused may be too much to expect in everyday practice. ${ }^{103}$
\end{abstract}

The Marshall Commission specifically recognized the problems inherent in a system that requires prosecutors to judge what is useful to the defence. The history of the Stinchcombe prosecution exemplifies the problem. The Crown prosecutor failed to apprehend the value, or usefulness, of the complainant's bankruptcy proceedings. Arguably, similar judgment errors were made in the prosecutions of Donald Marshall Jr. and David Milgaard, ${ }^{104}$ where additional witness statements or information were considered to be of limited use and miscarriages of justice resulted.

\title{
B. Remedies and SANCTIONS
}

Combined with the problem of connecting "relevance" with "usefulness to the defence," which the Supreme Court of Canada has failed to recognize, ${ }^{105}$ are issues arising in the imposition of remedies or sanctions by the courts for the failure of prosecutors to satisfy the disclosure obligation. The current state of the law in relation to remedies for failure to disclose has been summarized best by the Supreme Court of Canada in Dixon:

Andrusiw v. Aetna Life Insurance (2001), 289 A.R. 1 at 85 (Q.B.) [emphasis added] [hereinafter Aetna].

Nova Scotia, Royal Commission on the Donald Marshall, Jr. Prosecution: Commissioners' Report: Findings and Recommendations, vol. 1 (Halifax: The Commission, 1989) [hereinafter Marshall Commission]. 
The right to disclosure of all relevant material has a broad scope and includes material which may have only marginal value to the ultimate issues at trial. It follows that the Crown may fail to disclose information which meets the Stinchcombe threshold, but which could not possibly affect the reliability of the result reached or the overall fairness of the trial process. In those circumstances there would be no basis for granting the remedy of a new trial under s. 24(1) of the Charter, since no harm has been suffered by the accused. ${ }^{106}$

The focus, in relation to whether a remedy or sanction may be applied and what remedy is appropriate, is entirely upon the effect or impact of such non-disclosure or late disclosure upon the accused's right to make full answer and defence. The fact that there may have been a breach of the prosecutor's obligation to make full and proper disclosure, a duty cast as one of "utmost good faith," ${ }^{07}$ is largely irrelevant unless there has been prejudice to the right to make full answer and defence. In other words, no harm, no foul. This combination of the highest possible legal duty with a remedial framework that does not focus on encouraging compliance with that duty, independent of the prejudice or impact, is the failing of the current state of the law. The foul is the harm. And it is the foul (the failure to comply with the disclosure obligation simpliciter) that must be sanctioned, in some measure, regardless of the prejudice caused to the defence.

Without a remedy that focuses on compliance with the duty itself, there is little incentive for the prosecution to take seriously the constitutional requirement and "utmost" legal obligation to make full disclosure. ${ }^{108}$ The situation becomes even more problematic when one considers the effect of decisions such as $R$. v. Siemens, where the Alberta Court of Appeal held that the Crown can delegate the duty to review and catalogue disclosure to the Crown's agents, including the police. ${ }^{109}$ Imposing sanctions upon the prosecution that are dependent upon "marked and unacceptable departure[s]" 110 from the norm becomes difficult if the Crown prosecutor relies in good faith on an agent who does not have the same duty directly imposed on him or her. In such circumstances, Siemens simply serves to insulate the Crown prosecutor from the discharge of the duty. The foregoing difficulty arises, in the view of this author, as a result of the failure by Canadian Courts to take seriously Sopinka J.'s suggestion that the civil discovery process be used as a model for discovery in the criminal process.

At the time of the release of the judgment of the Supreme Court of Canada in Stinchcombe, the civil discovery process was relatively consistent across the common law provinces." The test to determine which documents were relevant and producible required little discretion on the part of the party litigants and, as summarized

roc Dixon, supra note 95 at 23.

107 Chaplin, supra note 57 at para. 21.

$10 \times$ For a more complete discussion, see the article by Glen Luther in this issue at 567.

10y $\quad R$ v. Siemens (1998), 122 C.C.C. (3d) 552 at paras. 27, $31-33$ (Alta. C.A.).

$110 \quad R$ v. 974649 Ontario (2001), 206 D.L.R. (4th) 444 at para. 87 (S.C.C.).

III See, e.g., Alberta, Rules of Court, r. 188 (as at 1991) and Ontario, Rules of Civil Procedure, r. 30.03(2), 30.03(4) (also as at 1991). These rules set out similar disclosure requirements relating to documents that have been in the parties' possession. 
by the Alberta Court of Appeal in Czuy v. Mitchell, was simply whether the documents touched upon "the matters in question." 12 In Ontario, the breadth of relevance and the obligation to produce documents is summarized, as a matter of current practice, in Ontario Annual Practice, 2001-2002, ${ }^{113}$ annotating Bensuro Holdings v. Avenor: ${ }^{14}$

Relevance for the purpose of disclosure under this rule constitutes a much broader and looser test of relevance than relevance at trial. Relevance for discovery embraces the "semblance" of relevance and so long as the documents in question "seem" to be relevant to the issues disclosed in the proceedings, they ought to be produced for inspection. The onus lies on the party resisting disclosure to justify its refusal. ${ }^{115}$

The current practice in Ontario, and until recently in Alberta, developed out of and relied upon the classic exposition of the broad classes of documents considered relevant found in Compagnie Financiere et Commerciale du Pacifique v. Peruvian Guano, where Brett L.J. stated,

It seems to me that every document relates to the matters in question in the action, which not only would be evidence upon any issue, but also which, it is reasonable to suppose, contains information which may - not which must - either directly or indirectly enable the party requiring the affidavit either to advance his own case or to damage the case of his adversary. I have put in the words "either directly or indirectly," because, as it seems to me, a document can properly be said to contain information which may enable the party requiring the affidavit either to advance his own case or to damage the case of his adversary, if it is a document which may fairly lead him to a train of inquiry, which may have either of these two consequences. ${ }^{116}$

Justice Sopinka, who had practiced as a civil litigator and written extensively on evidence and procedure, wrote Stinchcombe in the context of the broad discovery principles that were then applicable in civil procedure. The criminal pretrial disclosure procedure which he conceived in Stinchcombe was meant to adopt the civil procedure model of discovery and was necessarily founded upon that conception of broad discovery rights.

In civil proceedings, the question of whether counsel or a party litigant had failed to produce a document under such a broad and liberal test was relatively straightforward and easily ascertained. If a document simply "threw a light" on the case $^{117}$ or touched on "the matters in question,"118 it was producible. As suggested above, such a broad concept of disclosure was echoed by Sopinka J. in Stinchcombe

Czuy v. Mitchell (1976), 72 D.L.R. (3d) 424 at para. 249 (Alta. C.A.) [hereinafter Czuy]. J.J. Carthy, W.A.D. Millar \& J.G. Cowan, Ontario Annual Practice 200I-2002 (Aurora: Canada Law Book, 2001).

Bensuro Holdings v. Avenor (2000), 186 D.L.R. (4th) 182 (Ont. S.C.) [hereinafter Bensuro Holdings].

Ontario Annual Practice 2001-2002, supra note 113 at 269.

Compagnie Financiere et Commerciale du Pacifique v. Peruvian Guano (1882), 1I Q.B.D. 55 at 63 (C.A.) [hereinafter Peruvian Guano].

The phraseology used prior to Czuy, supra note 112; see, e.g., St. Regis Timber v. Lake Logging (1947), 3 D.L.R. 56 at 58 (B.C. C.A.) and O'Rourke v. Darbishire, [1920] A.C. 581 at 631 (H.L.). See $O^{\prime}$ Rourke v. Darbishire, ibid. at 630. 
where the prosecutor is admonished to "err on the side of inclusion" 119 and to refrain from producing only that which was "clearly irrelevant." 120

It is also important to note that, for the purposes of remedy, the civil discovery process specifically contemplates a variety of sanctions for non-disclosure, including a prohibition on the use of non-disclosed documents as part of the offending party's case. As a corollary, some case law suggests it is permissible to draw an adverse inference against the party which failed to produce the document, where the document was not helpful to the non-producing party. ${ }^{121}$ Failure to comply with the disclosure obligation may also result in contempt proceedings, with all of the remedies available thereunder, including the striking of claims or defences in more serious cases. ${ }^{122}$

Most significantly, however, there is an immediate, general sanction where a party fails to produce relevant documents and causes the opponent to make an application to enforce the disclosure obligations - that is, the sanction of costs. If a party is successful on such an application, the court routinely orders costs to be paid by the party litigant; or, in some cases, by counsel. The successful party is thereby indemnified, more or less, for the time and fees incurred in enforcing the obligation, and the opposing party is penalized. Since the parties are typically litigating over money, the imposition of a cost sanction is directly tied to the benefit to be achieved or avoided by the party litigants and, accordingly, there is a readily apparent incentive to comply with the disclosure obligation.

These remedies, particularly the general imposition of a cost sanction to ensure compliance in the civil discovery process, stand in sharp contrast to the remedial focus which has developed in the criminal process. Prior to Stinchcombe, the principle underlying the application of sanctions against the Crown was summarized in $R$. v. Douglas, a decision of the Ontario Court of Appeal. The case, affirmed by the Supreme Court of Canada without reasons, held that the focus of the remedy for an abuse of process or a failure on the part of the Crown "should, in general, be responsive to the violation. It should not be crafted to discipline the police or the Crown."123

111) Stinchcombe. supra note 1 at 339.

1201 Ibid. at 339

121 See, e.g., Brown v. MacDonald (1979). 37 N.S.R. (2d) 1 at 26-27, quoted in W.A. Stevenson \& J.E. Côté, Civil Procedure Guide: 1996 (Edmonton: Juriliber, 1996) at 814. See also H. Broom. A Selection of Legal Maxims, Classified and Illustrated, 10th ed. (London: Sweet and Maxwell. 1939) at 637-40; also as quoted in Stevenson \& Côté's Civil Procedure Guide at 809: "The maxim omnia praesumuntur contra spoliatorem [all is presumed against the despoiler or wrongdoer] can be applied to one who fails to produce a document which he is called on to produce."

See Alberta. Rules of Court, r. 703-704 and Ontario. Rules of Civil Procedure, r. 60.12. Cases where pleadings were struck (usually only in extreme circumstances of deliberate flouting of the rules) include Kin Franchising v. Donco. [1993] A.J. No. 40 (C.A.), online: QL (AJ) and Church of Scientology of Toronto v. Maritime Broadcasting (1979). 33 N.S.R. (2d) 500 (C.A.). In other cases, costs on a full or substantial indemnity basis were ordered; see, e.g.. Skipper Fisheries v. Thorbourne (1994), 137 N.S.R. (2d) 62 (S.C.).

13.3 $\quad$ R. v. Douglas (1991), 5 O.R. (3d) 29 at para. 2 (C.A.) [hereinafter Douglas] aflirmed without reasons [1993] 1 S.C.R. 893. See also R. v. Mack (1988), 44 C.C.C. (3d) 513. 
The focus of the remedy, as stated in Douglas in relation to abuse of process, has been implicitly adopted in cases involving failure on the part of the Crown to comply with the disclosure obligation imposed under Stinchcombe (generally, in relation to applications to stay the prosecution). The focus in these cases is not on the Crown's failure to perform its constitutional duty, but simply on redressing or compensating for the perceived prejudice. ${ }^{124}$

More recently, however, the Supreme Court of Canada has expanded its view of the objectives underlying the imposition of sanctions in a disclosure context. For example, in $R$. v. 974649 Ontario, the Court recognized the potential benefits of the cost sanction "as an effective remedy ... in enforcing the standards of disclosure established by this Court in $R$. v. Stinchcombe." 25 However, as stated by McLachlin C.J.C.,

\begin{abstract}
Such awards, while not without a compensatory element, are integrally connected to the court's control of its trial process, and intended as a means of disciplining and discouraging flagrant and unjustified incidents of non-disclosure.
\end{abstract}

Crown counsel is not held to a standard of perfection, and costs awards will not flow from every failure to disclose in a timely fashion. Rather, the developing jurisprudence uniformly restricts such awards, at a minimum, to circumstances of a marked and unacceptable departure from the reasonable standards expected of the prosecution. ${ }^{26}$

By thus focusing the remedy, there is no sanction except where there is demonstrable harm or where the failure is a marked departure from the norm. The foul becomes tolerable if it does no serious harm or is not a marked and unacceptable departure.

The principles underlying the imposition of cost sanctions fail to address the fact that any foul, whether a marked departure or not, is a breach of the duty of utmost good faith. Further, the foul forces an accused to bear the costs and delay associated with a disclosure application, even though the right to disclosure is constitutional and the duty breached by the Crown of the highest order. ${ }^{127}$ The problems associated with such a situation were described in a civil context by the Ontario High Court of Justice in Grossman v. Toronto General Hospital:

it becomes quickly clear to anyone setting out to practice in the courts that "production" is open to serious abuse. The integrity of the system depends upon the willingness of lawyers to require full and fair discovery of their clients. The system is, in a sense, in the hands of the lawyers. The opportunity for stonewalling and improper concealment is there. Some solicitors grasp it. They will make only such production as can be forced from them. That is bad practice. It can work real injustice. It causes delay

See, e.g., R. v. Carosella, [1997] I S.C.R. 80 at paras. 27, 37, 39; and R. v. Dixon, [1998] I S.C.R. 244 at para. 23.

125

126

127

Supra note 110 at para. 80.

Ibid. at paras. 81.87 [emphasis added].

The defence was compensated for none of the defence efforts throughout the various criminal proceedings - the only sanctions levied were new trials and adjournments. The effects of such sanctions (namely, costs and delays) were borne both by the Crown and the defence, notwithstanding that it was the Crown that breached its duty in the first place. 
and expense while the other side struggles to see that which they had a right to see from the first. In such a contest the advantage is to the long purse. ${ }^{128}$

Unfortunately, the remedial element of the civil discovery paradigm - which ensures, at a minimum, that a party who is put to the expense and trouble of enforcing the discovery obligation is routinely indemnified - has not been adopted by the courts in fashioning a criminal pretrial disclosure process. In conjunction with the failure to define relevance in a manner that avoids undue reliance on judgment calls by the Crown prosecutor, the model that has been created by the courts has significantly undermined the salutory and necessary principles enunciated in Stinchcombe.

\section{The falled Paradigm and lessons for Civil Procedure in Alberta}

It is against the backdrop of the apparent need for a formal discovery process in criminal law that Sopinka J. sought to adopt the civil discovery paradigm as an analogue. The failure to take that paradigm seriously and apply it rigorously, particularly in relation to the determination of the scope of relevance and the remedy or sanction imposed in relation to failures to disclose (which together create a disincentive for the defence to police or enforce the obligation), has rendered ineffective the developed criminal disclosure process. The faith that Sopinka J. expressed in his conception of an effective criminal pretrial disclosure process was, indeed, misplaced. ${ }^{129}$

The reform that is necessary to avoid the difficulties which have arisen following Stinchcombe is to incorporate the broad test for relevance that has been utilized in the civil discovery process for decades into the criminal law context and to (a) incorporate generally applied cost sanctions for a failure to comply with the obligation, based solely upon whether the defence was successful in their application for further disclosure and (b) to develop and more frequently apply remedies and sanctions to redress the prejudice to the accused arising from the failure to comply with the disclosure obligation and to create incentives for the prosecutor to fully comply with their high legal duty. In other words, what must be done is to create a culture in the criminal bar which does not tolerate the foul.

It is to be noted that, in a civil procedure context, the failure of a party litigant or counsel to comply with a duty of "utmost good faith"130 mandates, in many

Grossman v. Toronto General Hospital (1983), 146 D.L.R. (3d) 280 at 286 (Ont. H.C.J.) [hereinafter Grossman].

For a most recent example, review the disclosure history outlined in $R$. v. Trang, [2002] A.J. No. 1008 (Q.B.), online: QL (AJ) where Binder J. sets out, at paras. 192-318, a chronology of numerous defence requests, court orders and, ultimately, late disclosure in an admittedly complicated prosecution under the criminal organization provisions of the Criminal Code. Despite the necessity of the numerous procedural steps taken by the defence, no remedy (other than uncompensated adjournments) was granted and, in the result, the entire cost and delay associated with ensuring or enforcing compliance with Stinchcombe was borne by the defence.

Chaplin, supra note 57 at para. 21. 
circumstances, the imposition of punitive damages which are otherwise rare in civil litigation. ${ }^{131}$

The problems, uncertainties and disputes that have arisen in the criminal discovery process appear not to have been considered at the time of the incorporation of recent amendments to the Alberta Rules of Court relating to documentary and oral discovery. In 1999, the Alberta Rules of Court were amended to "substantially reduce the scope of this Rule [Rule 186] from the prior Rule which was very broad and all encompassing. It permitted discoverability if the documents 'touched the matters in question' and fell within the bounds of reasonableness." 132

The amended r. 186.1 now provides:

For the purpose of this Part, a question or record is relevant and material only if the answer to the question, or if the record, could reasonably be expected

(a) to significantly help determine one or more of the issues raised in the pleadings, or

(b) to ascertain evidence that could reasonably be expected to significantly help determine one or more of the issues raised in the pleadings. ${ }^{133}$

The amendments represent a marked departure from the tradition and culture of full and complete discovery of documents exposited in decisions spanning over a century, and ranging from Peruvian Guano in $1882,,^{134}$ to $C z u y$ in $1976^{135}$ and to Bensuro Holdings in $2000 .^{136}$

In this author's view, the amendments to the Alberta Rules of Court will cause problems in the civil discovery process akin to those which are being experienced in the criminal discovery process. The requirement for the party litigant or its counsel to assess "usefulness," defined as whether or not a document "could reasonably be expected to significantly help determine one or more of the issues raised in the pleadings," brings back the problem of judgment calls being made by party litigants or their counsel. The dangers of this discretion were, as previously discussed, foreseen by the Commissioner in the Royal Commission on the Donald Marshall, Jr. Prosecution. $^{137}$

The core of the concern with the amended discovery rules is found precisely in the area of the disclosure of documents where judgments are being made in the absence of opposing counsel or the adverse party litigants. As a result, the adverse party or counsel may never know of the existence of the document or be able to contest the judgment made in relation to the document's producibility. In the case of oral discovery,

\footnotetext{
See, e.g., Aetna, supra note 100.

132 D'Elia v. Dansereau (2000), 267 A.R. 157 (Q.B.), summarized in Liu v. West Edmonton Mall Property (2000), 279 A.R. 305 at para. 21 (Q.B.).

I3. Alta. Reg. 390/68, as am. by Alta. Reg. $172 / 99$ [emphasis added].

114 Supra note 116.

ins Supra note 112.

136 Supra note 114.

in Marshall Commission, supra note 101.
} 
at least the objection to the question is made in the presence of the opposing counsel and with an opportunity for dialogue and exchange of known positions.

The requirement that counsel or party litigants make judgment calls also signals an end to effective remedies or sanctions since, on application to the Courts for further or better disclosure, it may well be a complete answer to an alleged failure to disclose that the party litigant or counsel involved made a "good faith" judgment call. Imposing costs or punitive sanctions to enforce the disclosure obligation where a judgment call has been made on an issue upon which two parties may reasonably disagree is difficult. Accordingly, the requirement may decrease the incentive to comply with the disclosure obligation at first instance.

\section{CONCLUSION}

In the end, the very mischief that the traditional discovery process was meant to avoid, as outlined in Grossman, ${ }^{138}$ returns, and the collected wisdom and culture which have developed over the last century is put at significant risk. In my view, the justice system in Alberta stands on a dangerous precipice. To avoid the danger, it is imperative that counsel, law reform commissions and rules committees take disclosure and Stinchcombe seriously: they must return the civil discovery process, at least in relation to documentary discovery, to its traditional form and incorporate, fully, that discovery model in criminal proceedings. Only by doing so will Sopinka J.'s faith be vindicated. 